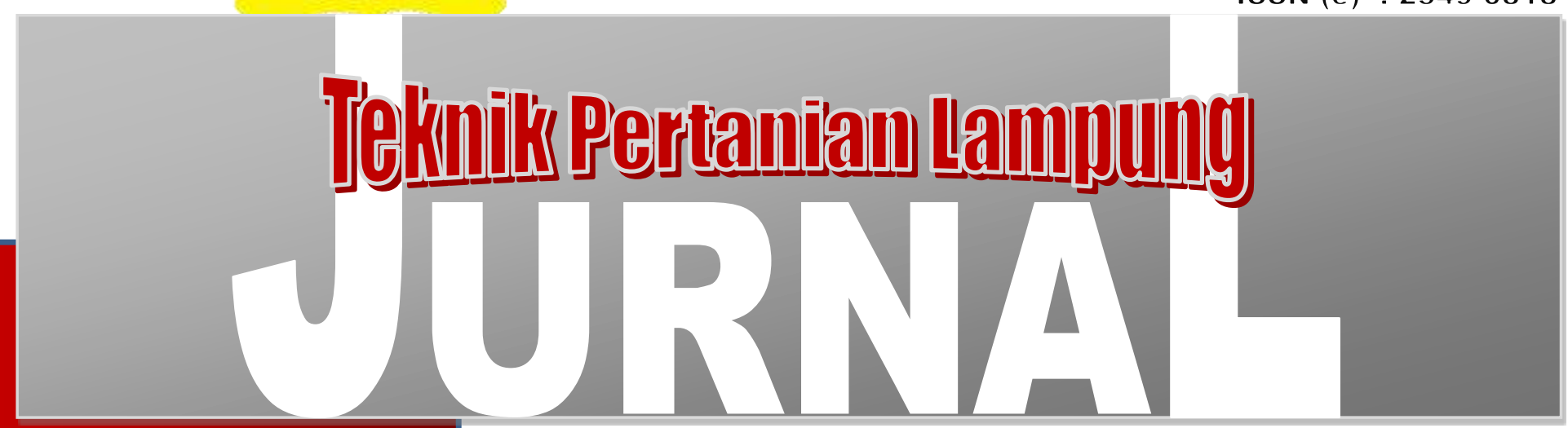

Vol. 7, No. 2, Agustus 2018 


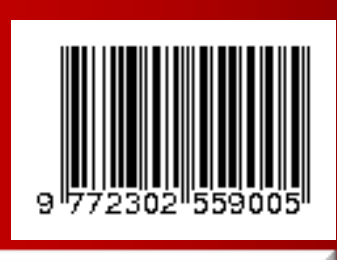


ISSN (p): 2302-559X

ISSN (e): 2549-0818

\section{Geanal TEKNIK PERTANIAN LAMPUNG}

\section{Vol. 7 No. 2, Agustus 2018}

Jurnal Teknik Pertanian (J-TEP) merupakan publikasi ilmiah yang memuat hasil-hasil penelitian, pengembangan, kajian atau gagasan dalam bidang keteknikan pertanian. Lingkup penulisan karya ilmiah dalam jurnal ini antara lain: rekayasa sumber daya air dan lahan, bangunan dan lingkungan pertanian, rekayasa bioproses dan penanganan pasca panen, daya dan alat mesin pertanian, energy terbarukan, dan system kendali dan kecerdasan buatan dalam bidang pertanian. J-TEP terbit sebanyak 3 (tiga) kali dalam satu tahun. Mulai tahun 2018 J-TEP menerbitkan jurnla pada bulan April, Agustus, dan Desember. J-TEP terbuka untuk umum, peneliti, mahasiswa, praktisi, dan pemerhati dalam dunia keteknikan pertanian.

\section{Ketua Editor}

Dr. Ir. Agus Haryanto, M.P

\section{Reviewer}

Prof. Dr. Ir, R.A. Bustomi Rosadi, M.S. (Manajemen Irigasi, Universitas Lampung)

Prof. Dr. Ir. Udin Hasanudin, M.T (Pengelolaan Limbah Agroindustri, Universitas Lampung)

Ir. Mimin Muhaemin, M.Eng., Ph.D (Mekanisasi Pertanian, Universitas Padjajaran)

Dr. Ir. Sugeng Triyono, M.Sc. (Rekayasa Sumberdaya Lahan dan Air, Universitas Lampung)

Dr. Eng Muhammad Makky (Teknik Biosistem, Universitas Andalas)

Dr. Diding Suhandy, S.TP., M.Agr (Spektroskopi, Universitas Lampung)

Dr. Ir. Wiludjeng Trisasiwi, MP (Energi Terbarukan, Universitas Jenderal Soedirman)

Dr. Sri Rahayoe, S.TP, M.P (Pengolahan Pangan, Universitas Gadjah Mada)

\section{Dewan Redaksi}

Ketua : Ahmad Tusi, S.TP, M.Si

Sekretaris : Cicih Sugianti, S.TP, M.Si

Anggota : Dr. Mareli Telaumbanuwa, S.TP, M.Sc

Winda Rahmawati, S.TP, M.Si., M.Sc

Tri Wahyu Saputra, S.T.P. M.Sc.

Jurnal Teknik Pertanian diterbitkan oleh Jurusan Teknik Pertanian, Universitas Lampung.

\section{Alamat Redaksi J-TEP:}

Jurusan Teknik Pertanian, Fakultas Pertanian

Universitas Lampung

Jl. Soemantri Brodjonegoro No.1

Telp. 0721-701609 ext. 846

Website :http://jurnal.fp.unila.ac.id/index.php/JTP

Email :jurnal tep@fp.unila.ac.id dan ae.journal@yahoo.com 


\section{PENGANTAR REDAKSI}

Dengan mengucapkan puji syukur kepada Allah yang Maha Kuasa, Jurnal Teknik Pertanian (JTEP) Volume 7 No 2 Tahun 2018 dapat diterbitkan. Pada edisi kali ini dimuat 7 (tujuh) artikel yang merupakan karya tulis ilmiah dari berbagai bidang kajian dalam dunia Keteknikan Pertanian yang meliputi modifikasi mesin peniris minyak dan analisis kelayakan produksi keripik bayam, kajian media tanam hidroponik dengan media baglog dan arang sekam, penentuan parameter kinetika pada sintesis biodeisel, evaluasi non-destrustif asam lemak bebas dengan spektroskopi, uji kinerja alat pengering jagung, unjuk kerja mesin pemotong padi, dan evaluasi mutu biji melinjo dengan citra digital.

Pada kesempatan kali ini kami menyampaikan ucapan terima kasih yang sebesar-besarnya kepada para penulis atas kontribusinya dalam Jurnal TEP dan kepada para reviewer/penelaah jurnal ini atas peran sertanya dalam meningkatkan mutu karya tulis ilmiah yang diterbitkan dalam edisi ini.

Akhir kata, semoga Jurnal TEP ini dapat bermanfaat bagi masyarakat dan memberikan konstribusi yang berarti bagi pengembangan ilmu pengetahuan dan teknologi, khususnya di bidang keteknikan pertanian.

\section{Redaksi J TEP-Lampung}

ISSN (p): 2302-559X

ISSN (e): 2549-0818 


\section{Gencual TEKNIK PERTANIAN LAMPUNG}

Vol. 7 No. 2, Agustus 2018

Halaman

Daftar isi

Pengantar Redaksi

MODIFIKASI MESIN PENIRIS MINYAK DAN KELAYAKAN FINANSIAL PRODUKSI

KERIPIK BAYAM

Ahmad Thoriq, Totok Herwanto, Drupadi Ciptaningtyas

PENENTUAN NILAI PARAMETER KINETIKA ORDE SATU PADA SINTESIS BIODIESEL DARI MINYAK JELANTAH

Amieria Citra Gita, Agus Haryanto, Tri Wahyu Saputra, Mareli Telaumbanua

EVALUASI NON-DESTRUKTIF KANDUNGAN ASAM LEMAK BEBAS (ALB)

80-87

TANDAN BUAH SEGAR (TBS) KELAPA SAWIT DENGAN METODE NIR

SPEKTROSKOPI

Zaqlul Iqbal, Sam Herodian, Slamet Widodo

UJI KINERJA ALAT PENGERING SILINDER VERTIKAL PADA PROSES

$88-96$

PENGERINGAN JAGUNG (Zea mays ssp.mays)

Made Aditya Putra, Sandi Asmara, Cicih Sugianti, Tamrin

UNJUK KERJA MESIN PEMOTONG PADI (PADDY MOWER) SAAT PEMANENAN

PADI (Oryza Sativa L.) DI LAHAN BASAH

Siti Anisa, Siti Suharyatun, Oktafri, Sandi Asmara

EVALUASI MUTU BIJI MELINJO (Gnetum gnemon L.) MENGGUNAKAN

PENGOLAHAN CITRA DIGITAL

Slamet Widodo dan Muhammad Kalili

KAJIAN MEDIA TANAM HIDROPONIK DARI CAMPURAN BAHAN BAKU LIMBAH BAGLOG DAN ARANG SEKAM

Dyah Isworo, Sugeng Triyono, Agus Haryanto, Iskandar Zulkarnain 


\section{PEDOMAN PENULISAN ARTIKEL BAGI PENULIS}

1) Naskah: Redaksi menerima sumbangan naskah/tulisan ilmiah dalam bahasa Indonesia atau bahasa Inggris, dengan batasan sebagai berikut :

a. Naskah diketik pada kertas ukuran A4 $(210 \mathrm{~mm}$ x $297 \mathrm{~mm})$ dengan 2 spasi dan ukuran huruf Times New Roman 12pt. Jarak tepi kiri, kanan, atas, dan bawah masing-masing $3 \mathrm{~cm}$. Panjang naskah tidak melebihi 20 halaman termasuk abstrak, daftar pustaka, tabel dan gambar. Semua tabel dan gambar ditempatkan terpisah pada bagian akhir naskah (tidak disisipkan dalam naskah) dengan penomoran sesuai dengan yang tertera dalam naskah. Naskah disusun dengan urutan sebagai berikut: Judul; Nama Penulis disertai dengan catatan kaki tentang instansi tempat bekerja; Pendahuluan; Bahan dan Metode; Hasil dan Pembahasan; Kesimpulan dan Saran; Daftar Pustaka; serta Lampiran jika diperlukan. Template penulisan dapat didownload di http://jurnal.fp.unila.ac.id/index.php/JTP

b. Abstrak (Abstract) dalam bahasa Indonesia dan bahasa Inggris, tidak lebih dari 200 kata. Mengandung informasi yang tertuang dalam penulisan dan mudah untuk dipahami. Ringkasan (abstract) harus memuat secara singkat latar belakang, tujuan, metode, serta kesimpulan dan yang merupakan high light hasil penelitian.

c. Pendahuluan: memuat latar belakang masalah yang mendorong dilaksanakannya perekayasaan dan penelitian, sitasi dari temuan-temuan terdahulu yang berkaitan dan relevan, serta tujuan perekayasaan atau penelitian.

d. Bahan dan Metoda: secara jelas menerangkan bahan dan metodologi yang digunakan dalam perekayasaan atau penelitian berikut dengan lokasi dan waktu pelaksanaan, serta analisis statistik yang digunakan. Rujukan diberikan kepada metoda yang spesifik.

e. Hasil dan Pembahasan: Memuat hasil-hasil perekayasaan atau penelitian yang diperoleh dan kaitannya dengan bagaimana hasil tersebut dapat memecahkan masalah serta implikasinya. Persamaan dan perbedaannya dengan hasil perekayasaan atau penelitian terdahulu serta prospek pengembangannya. Hasil dapat disajikan dengan menampilkan gambar, grafik, ataupun tabel.

f. Kesimpulan dan Saran: memuat hal-hal penting dari hasil penelitian dan kontribusinya untuk mengatasi masalah serta saran yang diperlukan untuk arah perekayasaan dan penelitian lebih lanjut.

g. Daftar Pustaka: disusun secara alfabetis menurut penulis, dengan susunan dan format sebagai berikut: Nama penulis didahului nama family/nama terakhir diikuti huruf pertama nama kecil atau nama pertama. Untuk penulis kedua dan seterusnya ditulis kebalikannya. Contoh:

- Kepustakaan dari Jurnal:

Tusi, Ahmad, dan R.A. Bustomi Rosadi. 2009. Aplikasi Irigasi Defisit pada Tanaman Jagung. Jurnal Irigasi. 4(2): 120-130.

- Kepustakaan dari Buku:

Keller, J., and R.D. Bleisner. 1990. Sprinkle and Trickle Irrigation. AVI Publishing Company Inc. New York, USA.

h. Satuan: Satuan harus menggunakan system internasional (SI), contoh : $\mathrm{m}$ (meter), $\mathrm{N}$ (newton), ${ }^{\circ} \mathrm{C}$ (temperature), kW dan W (daya), dll.

2) PenyampaianNaskah:Naskah/karya ilmiah dapat dikirimkan ke alamatdalambentuksoft copyke :

Redaksi J-TEP(JurnalTeknikPertanianUnila)

Jurusan Teknik Pertanian, Fakultas Pertanian

Universitas Lampung

Jl. Sumantri Brodjonegoro No. 1

Telp. 0721-701609 ext. 846

Website : http://jurnal.fp.unila.ac.id/index.php/JTP

Email : jurnal.tep@fp.unila.ac.id atau ae.journal@yahoo.com

3) Selama proses penerimaan karya ilmiah, penelaahan oleh Reviewer, sampai diterimanya makalah untuk diterbitkan dalam jurnal akan dikonfirmasi kepada penulis melalui email.

4) Reviewer berhak melakukan penilaian, koreksi, menambah atau mengurangi isi naskah/tulisan bila dianggap perlu, tanpa mengurangi maksud dan tujuan penulisan. 


\title{
MODIFIKASI MESIN PENIRIS MINYAK DAN KELAYAKAN FINANSIAL PRODUKSI KERIPIK BAYAM
}

\section{MODIFICATION OF SPINNER MACHINE AND FINANCIAL FEASIBILITY OF PRODUCTION BREAD CHIPS}

\author{
Ahmad Thoriq ${ }^{1 凶}$, Totok Herwanto ${ }^{1}$, Drupadi Ciptaningtyas ${ }^{1}$ \\ ${ }^{1)}$ Departemen Teknik Pertanian dan Biosistem, Fakultas Teknologi Industri Pertanian Universitas Padjadjaran, \\ Jl. Raya Bandung Sumedang KM 21, Jatinangor 40600 \\ ${ }^{\otimes}$ komunikasi penulis, Email : thoriq@unpad.ac.id \\ DOI:http://dx.doi.org/10.23960/jtep-lv7i2.63-71
}

Naskah ini diterima pada 26 Juli 2018; revisi pada 3 Agustus 2018; disetujui untuk dipublikasikan pada 10 Agustus 2018

\begin{abstract}
Spinach cracker is one of the snack products with the main ingredients of fried spinach leaves saluted using flour. The quality of spinach chips is influenced by the amount of oil remnant contained in spinach chips. The use of spinner machine can reduce or eliminate the oil content quickly and improve the quality of the product but the machine available on the market can not be used to drain the oil contained in spinach chips because the rotational speed is set up by more than 400 rpm so that causing damage of the chips. This study aims to modify the spinner by lowering the speed of rotation and evaluate the financial feasibility analysis of spinach chips production. The method used in this research includes engineering design approach and financial feasibility. The design approach consists of problems identification, formulation of modification concept, functional and performance test while some parameters calculated in financial feasibility analysis are: cost of production (HPP), net present value (NPV), benefit cost ratio (BCR), internal rate of return (IRR), and payback period (PBP). The results showed that decreasing rotational speed from $532.50 \mathrm{rpm}$ to $258.18 \mathrm{rpm}$ was able to remove the oil remnant on spinach chips and avoid the damage of spinach chips from $50 \%$ to $0 \%$. At a production capacity of spinach chips $150 \mathrm{~kg} /$ month the cost of production amounted to IDR.43,087 $/ \mathrm{kg}$. Using spinach chips selling price of IDR.50,000 / kg, the spinach chips production was economically feasible with NPV of IDR.15,088,782/ month, BCR of 1.10, IRR of $12 \%$ and PBP of 8 months.
\end{abstract}

Keywords: engine modification, oil slicer, financial feasibility, spinach chips

\begin{abstract}
ABSTRAK
Keripik bayam merupakan salah satu produk cemilan dengan bahan utama bayam yang digoreng menggunakan tepung. Mutu keripik bayam sangat dipengaruhi banyaknya kandungan minyak yang terdapat pada keripik bayam. Penggunaan mesin spinner terbukti dapat mengurangi atau menghilangkan kandungan minyak secara cepat dan meningkatkan kualitas produk namun mesin spinner yang tersedia di pasaran tidak dapat digunakan untuk meniriskan minyak yang terdapat pada keripik bayam karena memiliki kecepatan putar lebih dari 400 rpm sehingga dapat menyebabkan kerusakan keripik bayam. Penelitian ini bertujuan melakukan modifikasi spinner dengan cara menurunkan kecepatan putar dan melakukan analisis kelayakan finansial usaha produksi keripik bayam. Metode yang digunakan pada penelitian ini yaitu melalui pendekatan rancangan teknik dan kelayakan finansial suatu usaha. Pendekatan rancangan teknik terdiri atas identifikasi masalah, perumusan konsep modofikasi, uji fungsional dan uji kinerja mesin sedangkan beberapa parameter yang dihitung pada analisis kelayakan finansial antara lain : harga pokok produksi (HPP), net present value (NPV), benefit cost ratio (BCR), internal rate of return (IRR), dan payback period (PBP). Hasil penelitian menunjukkan penurunan kecepatan putar dari 532,50 rpm menjadi 258,18 rpm terbukti tetap dapat mengeluarkan kandungan minyak pada keripik bayam dan menghindari terjadinya kerusakan keripik bayam dari 50\% menjadi $0 \%$. Pada kapasitas produksi keripik bayam $150 \mathrm{~kg} /$ bulan didapatkan harga pokok produksi sebesar Rp.43.087 / kg. Bila keripik bayam dijual dengan harga pasar Rp.50.000/kg didapatkan NPV sebesar Rp. 15.088.782/bulan, BCR sebesar 1,10, IRR sebesar $12 \%$ dan modal akan kembali pada bulan ke delapan.
\end{abstract}

Kata kunci : Modifikasi mesin, peniris minyak, kelayakan finansial, keripik bayam 


\section{PENDAHULUAN}

Keripik bayam merupakan salah satu produk cemilan dengan bahan utama bayam yang digoreng menggunakan tepung. Proporsi campuran tepung pada keripik bayam yang disukai adalah perbandingan tepung tapioka dan mocaf sebanyak 60:40 serta penambahan maltodekstrin 0,2 \% (Razak dan Apriyanto 2014). Faktor utama yang berpengaruh signifikan terhadap minat beli minat beli keripik bayam adalah mutu, harga dan kemasan (Amizah 2014). Mutu keripik bayam sangat dipengaruhi banyaknya kandungan minyak yang terdapat pada keripik bayam. Alat yang digunakan untuk mengurangi kandungan minyak secara manual adalah alat peniris minyak namun penggunaan alat peniris minyak belum dapat mengurangi kandungan minyak dengan cepat dan optimal yang berimplikasi pada umur simpan keripik bayam yang hanya bertahan 3 hari dan setelahnya keripik bayam menjadi tengik dan tidak gurih (Utami dan Azinar 2017). Penggunaan mesin spinner sangat membantu dalam mengurangi atau menghilangkan kandungan minyak secara cepat dan meningkatkan kualitas produk. Prinsip kenrja spinner yaitu mengurangi kandungan minyak bahan dengan menggunakan teknik putaran tinggi (sentrifuge) sehingga mampu menarik sebagian minyak keluar dari bahan (Wulandari dan Nunuk 2009). Pada pengujian menggunakan keripik singkong, spinner dengan diameter tabung $320 \mathrm{~mm}$, tinggi $350 \mathrm{~mm}$ dan putaran $840 \mathrm{rpm}$ memiliki kapasitas optimal yang mencapai mencapai 35,51 kg/jam (Ilham 2017). Namun demikian spinner yang tersedia di pasaran tidak dapat digunakan untuk meniriskan minyak yang terdapat pada keripik bayam hal ini karena pada umumnya spinner didesain untuk mengurangi kandungan minyak pada keripik singkong, keripik ubi dan atau keripik pisang sehingga kecepatan putar di setting lebih dari 400 rpm (Hamimi dkk 2011). Kecepatan putar optimal dalam proses penirisan minyak terjadi pada $550 \mathrm{rpm}$ (Sugandi et al.2018). Pada uji coba awal dengan kecepatan putar diatas $400 \mathrm{rpm}$ terdapat banyak keripik bayam yang mengalami kerusakan yang berimplikasi pada menurunya daya beli konsumen karena penampilan produk yang tidak menarik.
Penelitian ini bertujuan melakukan modifikasi spinner dengan cara menurunkan kecepatan putar guna meningkatkan kualitas produk keripik bayam dan melakukan analisis kelayakan finansial usaha produksi keripik bayam.

\section{BAHAN DAN METODE}

\subsection{Waktu dan Tempat}

Penelitian dilakukan pada bulan Juni hingga Desember 2017 bertempat di Usaha Kecil Menengah Aneka Keripik Desa Cileles, Kecamatan Jatinangor, Kabupaten Sumedang.

\subsection{Bahan dan Alat}

Bahan yang digunakan pada penelitian ini antara lain belt dan pulley dengan beberapa variasi ukuran, dan keripik bayam dalam kondisi utuh atau tidak rusak. Sedangkan peralatan yang digunakan pada penelitian ini adalah kunci inggris, mesin bubut, clamp meter, stop watch, timbangan digital, nampan, dan alat tulis.

\subsection{Prosedur Penelitian}

\subsubsection{Modifikasi dan uji kinerja spinner}

Penelitian ini diawali dengan modifikasi belt dan pulley untuk memperkecil putaran mesin spinner. Untuk mendapatkan kualitas produk yang keripik bayam yang baik, dilakukan uji coba dengan beberapa kecepatan putar spinner. Penurunan kecepatan putar spinner menggunakan persamaan 1 .

Rpm spinner $=(\mathrm{N} 1 / \mathrm{N} 2) \mathrm{x}$ rpm motor listrik

Dimana N1 adalah diameter pulley yang terhubung pada motor listrik (inchi), N2 adalah diameter pulley yang terhubung pada tabung spinner (inchi) dan putaran motor listrik 0,25 HP adalah $1420 \mathrm{rpm}$. Perbandingan pulley saat ini adalah $\mathrm{N} 1=3$ inchi dan N2 = 8 inchi.

Menggunakan persamaan 1 dihasilkan putaran spinner sebesar 532,50 rpm. Penurunan putaran spinner dilakukan melalui beberapa variasi seperti dapat dilihat pada Tabel 1.

Waktu pengujian yang dilakukan berdasarkan kecepatan putaran silinder (rpm) pada penelitian ini adalah 40, 60 dan 80 detik (Hamimi dkk, 2011) menggunakan keripik bayam dalam kondisi utuh atau tidak rusak. 
Tabel 1. Rencana modifikasi dengan beberapa variasi putaran spinner

\begin{tabular}{ccc}
\hline $\begin{array}{c}\text { N1 } \\
\text { (inchi) }\end{array}$ & $\begin{array}{c}\text { N2 } \\
\text { (inchi) }\end{array}$ & $\begin{array}{c}\text { Putaran silinder } \\
\text { spinner (rpm) }\end{array}$ \\
\hline 2 & 11 & 258,18 \\
2 & 8 & 355,00 \\
3 & 11 & 387,27 \\
3 & 8 & 532,50 \\
\hline
\end{tabular}

2.3.2 Analisis kerusakan keripik bayam

Pengujian mesin untuk menganalisis kerusakan keripik bayam dilakukan sebanyak 4 (empat) kali ulangan. Persentase kerusakan keripik bayam dihitung berdasarkan banyaknya keripik bayam yang rusak (KBr) dibagi dengan berat awal keripik bayam (KBa) dikalikan seratus persen yang dirumuskan sebagai berikut:

$\% \mathrm{KBr}=(\mathrm{KBr} / \mathrm{KBa}) \times 100$

\subsubsection{Analisis Kelayakan Finansial}

Perhitungan kelayakan finansial diawali dengan menghitung besarnya biaya penyusutan peralatan produksi menggunakan metode garis lurus yang dirumuskan sebagai berikut:

$$
D=\frac{P-S}{N}
$$

Dimana D merupakan biaya penyusutan pertahun ( $\mathrm{Rp} /$ tahun), $\mathrm{P}$ adalah harga awal peralatan (Rp), $\mathrm{S}$ adalah harga akhir peralatan (Rp) dan $\mathrm{N}$ adalah perkiraan umur ekonomis (tahun). Sedangkan besarnya anggsuran pinjaman di perhitungkan menggunakan persamaan bunga anuitas dengan bunga tetap sebagai berikut :

$$
A=P x^{*}(i / 12) *(1+i / 12) n /(1+i / 12) n-1(4)
$$

Dimana A merupakan besarnya angsuran yang harus dibayarkan (Rp/bulan), Px adalah besarnya pinjaman (Rp), $n$ adalah lama pinjaman (tahun) dan i adalah suku bunga (\%/tahun). Besarnya suku bunga yang diacu pada penelitian ini adalah suku bunga kredit usaha rakyar mikro PT. Bank Republik Indonesia, Tbk yaitu sebesar 9\% efektif pertahun.

Suatu usaha dikatakan layak apabila Net Present Value (NPV) $>0$, Benefit Cost Ratio (BCR) $>1$, Internal Rate of Return (IRR) > Suku bunga MARR, dan pengembalian modal yang cepat.
Jurnal Teknik Pertanian Lampung Vol.7, No. 2: 63-71

Besarnya NPV, BCR dan IRR dihitung menggunakan persamaan berikut (Kastaman, 2004):

$\mathrm{NPV}=(\Sigma \mathrm{PVin})-(\Sigma \mathrm{PVout})$

$\mathrm{BCR}=\frac{(\Sigma \text { PVin })}{(\Sigma \text { PVout }}$

dimana PVin merupakan nilai sekarang bersih dari perhitungan dana masuk, PVout merupakan nilai sekarang bersih dari perhitungan dana keluar selama jangka waktu analisis.

Perhitungan IRR menggunakan fungsi yang terdapat pada Microsoft office excel berdasarkan data pendapatan bersih selama jangka waktu analisis yaitu 24 bulan menggunakan persamaan 7.

IRR(data ke-1 : data ke-24)

\section{HASIL DAN PEMBAHASAN}

\subsection{Modifikasi dan Uji Kinerja Mesin Spinner}

Konstruksi mesin spinner yang dimodifikasi digerakkan dengan motor listrik $1 / 3 \mathrm{HP}$ atau $0,25 \mathrm{~kW}$ dengan putaran $1420 \mathrm{rpm}$ yang ditransmisikan menggunakan pulley dengan perbandingan $3: 8$ inchi dan belt tipe B65. Secara keseluruhan, mesin spinner memiliki panjang 58 $\mathrm{cm}$, lebar $40 \mathrm{~cm}$ dan tinggi $76 \mathrm{~cm}$. Silinder spinner bagian dalam sebagai penampung produk yang akan tiriskan berdiameter $30 \mathrm{~cm}$ dengan tinggi $25 \mathrm{~cm}$ sedangkan silinder spinner bagian luar sebagai penampung dan mengeluarkan minyak melalui lubang pengeluaran berdiameter $40 \mathrm{~cm}$ dengan tinggi $35 \mathrm{~cm}$. Komponen dan bagianbagian mesin spinner dapat dilihat pada Gambar 1.

Pengujian dilakukan menggunakan keripik bayam dengan beberapa variasi kecepatan putaran silinder spinner. Keripik bayam memiliki karakteristik fisik yang tipis dan mudah rusak dibandingkan dengan keripik singkong, keripik ubi jalar dan atau keripik pisang, sehingga proses penyusunan keripik bayam pada silinder spinner dilakukan secara hati-hati. Kondisi awal keripik bayam sebelum masuk ke spinner dapat dilihat pada Gambar 2. 


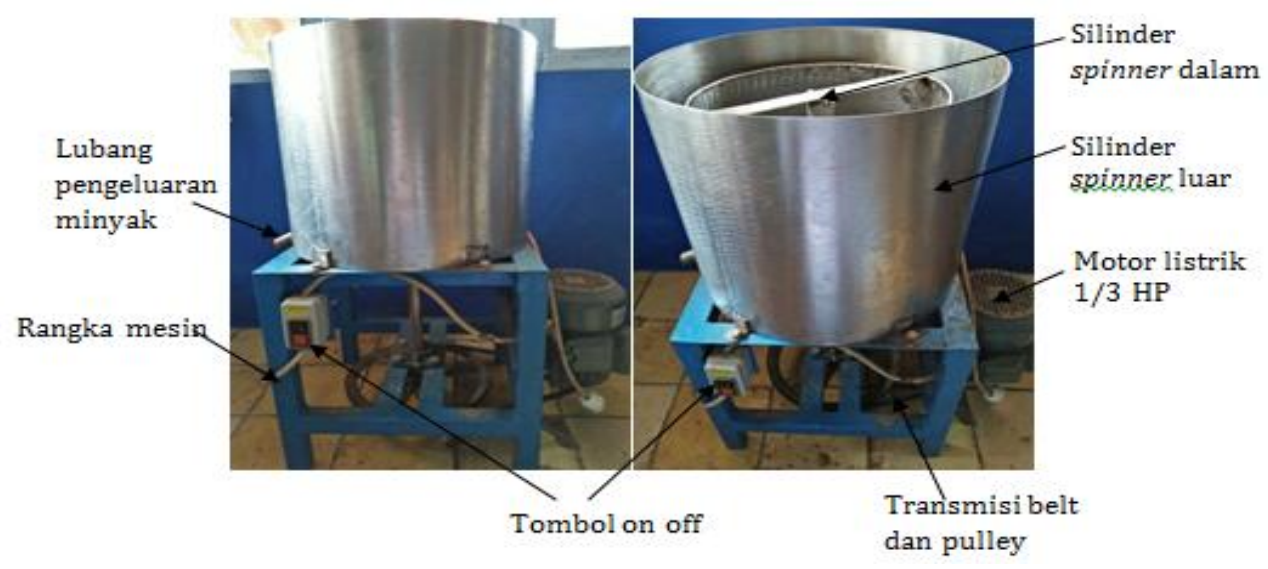

Gambar 1. Konstruksi mesin spinner dan bagian-bagiannya

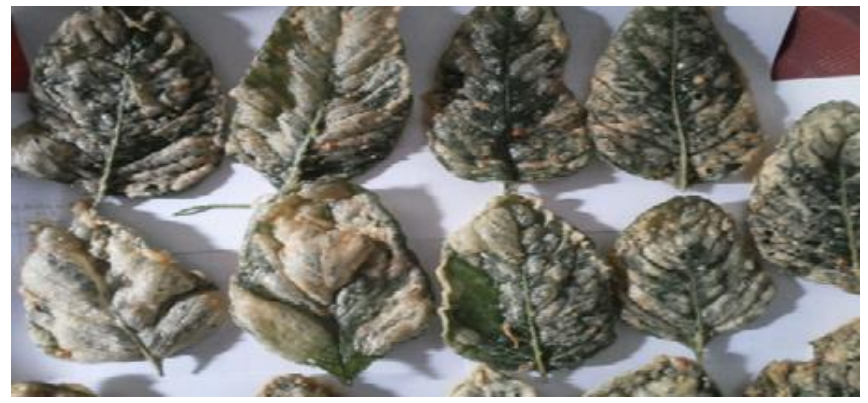

Gambar 2. Kondisi awal keripik bayam sebelum pengujian

Tabel 2. Kerusakan keripik bayam berdasarkan putaran spinner

\begin{tabular}{cccc}
\hline $\begin{array}{c}\text { N1 } \\
\text { (inchi) }\end{array}$ & $\begin{array}{c}\text { N2 } \\
\text { (inchi) }\end{array}$ & $\begin{array}{c}\text { Putaran } \\
\text { spinner (RPM) }\end{array}$ & $\begin{array}{c}\text { Kerusakan } \\
\text { keripik } \\
\text { bayam } \\
\text { (\%) }\end{array}$ \\
\hline 3 & 8 & 532,50 & 50 \\
3 & 11 & 387,27 & 5 \\
2 & 8 & 355,00 & 5 \\
2 & 11 & 258,18 & 0 \\
\hline
\end{tabular}

Berdasarkan Tabel 2 terlihat bahwa kerusakan keripik bayam pada putaran spinner awal (532,5 rpm) sebesar 50\% sedangkan pada kecepatan putar spinner 258,18 rpm tidak ada keripik bayam yang mengalami kerusakan. Kerusakan keripik bayam dapat dilihat pada Gambar 2.

Kerusakan tersebut mempengaruhi nilai jual dan daya saing produk keripik bayam. Pada kecepatan putaran spinner $355 \mathrm{rpm}$ dan 387,27 rpm kerusakan yang terjadi berupa pengelupasan tepung pada keripik bayam, kerusakan yang terjadi sebesar 5\%. Menurut Hamimi dkk (2011) pada kecepatan putaran silinder spinner 400 - 500 rpm dalam waktu 4080 detik terjadi kerusakan keripik singkong sebanyak 2,67 - 6\%, keripik pisang sebanyak 2$10 \%$ dan keripik ubi jalar sebanyak 5,5 $14,83 \%$.
Berdasarkan hasil pengujian tersebut maka dipilih diameter pulley yang terhubung pada motor listrik (N1) adalah 2 inchi sedangkan yang terhubung dengan silinder spinner dalam (N2) adalah 11 inchi yang disambungkan dengan belt tipe A25.

Kerusakan tersebut mempengaruhi nilai jual dan daya saing produk keripik bayam. Pada kecepatan putaran spinner $355 \mathrm{rpm}$ dan 387,27 rpm kerusakan yang terjadi berupa pengelupasan tepung pada keripik bayam, kerusakan yang terjadi sebesar $5 \%$. Menurut Hamimi dkk (2011) pada kecepatan putaran silinder spinner 400 - 500 rpm dalam waktu 4080 detik terjadi kerusakan keripik singkong sebanyak 2,67 - 6\%, keripik pisang sebanyak 2$10 \%$ dan keripik ubi jalar sebanyak 5,5 $14,83 \%$.

Berdasarkan hasil pengujian tersebut maka dipilih diameter pulley yang terhubung pada motor listrik (N1) adalah 2 inchi sedangkan yang terhubung dengan silinder spinner dalam (N2) adalah 11 inchi yang disambungkan dengan belt tipe A25. 


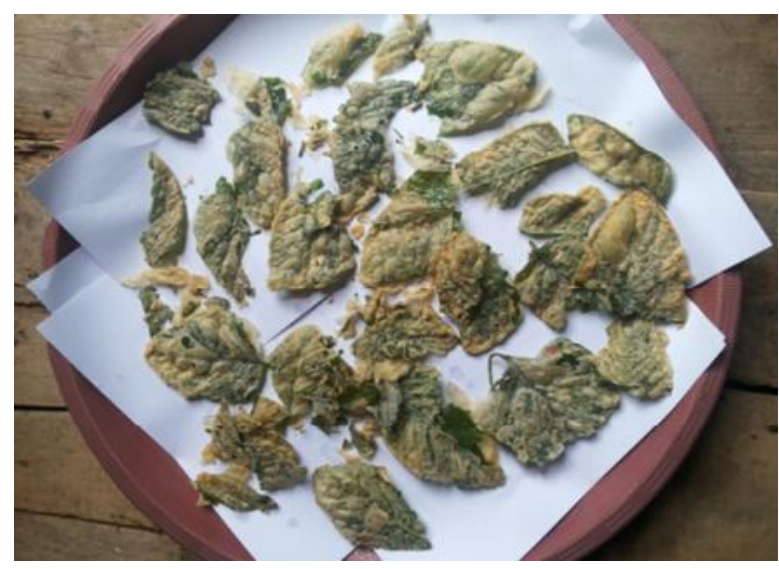

Gambar 3. Kerusakan keripik bayam pada 532,5 rpm

\subsection{Analisis Kelayakan Finansial}

Analisis kelayakan finansial usaha produksi keripik bayam dilakukan dengan asumsi umur proyek 2 tahun dengan pertimbangan. Perhitungan kelayakan finansial diawali dengan penentuan biaya investasi peralatan, selanjutnya ditentukan variabel asumsi dari usaha yang akan dilakukan. Rincian biaya investasi dapat dilihat pada Tabel 3.
Besarnya nilai investasi tersebut digunakan untuk menghitung besarnya biaya penyusutan peralatan dan bunga modal yang akan mempengaruhi biaya produksi. Biaya penyusutan diperhitungkan menggunakan metode garis lurus sedangkan biaya bunga modal berasal dari asumsi bahwa seluruh biaya investasi peralatan dan modal kerja pembelian bahan baku dalam satu bulan adalah dana

Tabel 3. Biaya investasi produksi keripik bayam

\begin{tabular}{clcccc}
\hline No & Nama peralatan & Jumlah & Satuan & $\begin{array}{c}\text { Harga Satuan } \\
\text { (Rp) }\end{array}$ & $\begin{array}{c}\text { Harga Total } \\
\text { (Rp) }\end{array}$ \\
\hline 1 & Baskom besar & 2 & Buah & 35.000 & 70.000 \\
2 & Tampah & 2 & Buah & 25.000 & 50.000 \\
3 & Sealer press & 1 & Unit & 235.000 & 235.000 \\
4 & Spinner & 1 & Unit & 2.200 .000 & 2.200 .000 \\
5 & Kuali No.31 & 2 & Buah & 35.000 & 70.000 \\
6 & Kompor gas + tabung gas & 1 & Unit & 600.000 & 600.000 \\
7 & Irus & 2 & Buah & 30.000 & 60.000 \\
8 & Batu Uleg & 1 & Unit & 60.000 & 60.000 \\
9 & Ember besar 30 ltr & 2 & Buah & 60.000 & 120.000 \\
\hline \multicolumn{5}{r}{} \\
\hline \multicolumn{7}{r}{} & Jumlah (Rp) & & \\
\hline
\end{tabular}

Tabel 4. Bahan baku pembuatan keripik bayam

\begin{tabular}{llccc}
\hline No & Nama Bahan & Kuantitas (Kg) & $\begin{array}{c}\text { Harga Satuan } \\
(\mathbf{R p} / \mathbf{k g})\end{array}$ & $\begin{array}{c}\text { Harga Total } \\
(\mathbf{R p})\end{array}$ \\
\hline 1 & Bayam & $2 \mathrm{~kg}$ & 12.000 & 24.000 \\
2 & Minyak goreng & $1 \mathrm{liter}$ & 12.000 & 12.000 \\
3 & Tepung beras & $0,2 \mathrm{~kg}$ & 16.000 & 3.200 \\
4 & Tepung tapioka & $0,2 \mathrm{~kg}$ & 12.600 & 2.520 \\
5 & Tepung terigu & $0,1 \mathrm{~kg}$ & 9.000 & 900 \\
6 & Telur & 0,130 & 25.000 & 3.250 \\
7 & Bawang putih & $0,02 \mathrm{~kg}$ & 25.000 & 500 \\
8 & Penyedap rasa & 1 bungkus & 1.000 & 1.000 \\
\hline & & & $\mathbf{4 7 . 3 7 0}$ \\
\hline
\end{tabular}


pinjaman dari lembaga keuangan. Banyaknya bahan baku pembuatan keripik bayam dalam satu bulan diperhitungkan berdasarkan kapasitas efektif penirisan yaitu $0,25 \mathrm{~kg} /$ menit atau setara dengan $15 \mathrm{~kg} / \mathrm{jam}$, dengan asumsi operasi mesin 1 jam/hari dan 10 hari/bulan serta bahan baku pembuatan keripik bayam sebagaimana dapat dilihat pada Tabel 4.

Berdasarkan Tabel 4 terlihat bahwa untuk menghasilkan $2 \mathrm{~kg}$ keripik bayam dibutuhkan biaya sebesar Rp. 47.370 sehingga biaya bahan baku dalam sebulan adalah sebesar Rp. 3.552.750. Berdasarkan perhitungan tersebut, maka besanya dana yang harus dipinjam ke lembaga keuangan adalah Rp. 7.158.105 (dibulatkan menjadi Rp. 7.200.000) yang merupakan penjumlahan dari biaya investasi ditambah biaya bahan baku, biaya administrasi dan asuransi pinjaman ( $2 \%$ dari pinjaman) untuk skema pinjaman 1 tahun dengan tingkat suku bunga KUR 9\% pertahun.

Perhitungan biaya produksi dilakukan berdasarkan data dan beberapa asumsi (Wijayanti dkk, 2011 ; Pertiwi dan Purnama, 2011; Thoriq dkk, 2017) yang dapat dilihat pada Tabel 5.

\subsection{Penentuan Biaya Produksi dan Harga Pokok Produksi Keripik Bayam}

Biaya produksi keripik bayam dipengaruhi oleh biaya tetap dan biaya variabel. Bila usaha dikelola secara profesional maka dalam perhitungan biaya tetap diasumsikan mengeluarkan biaya sewa

Tabel 5. Variabel asumsi produksi keripik bayam

\begin{tabular}{clcc}
\hline No & \multicolumn{1}{c}{ Uraian } & Nilai & Satuan \\
\hline 1 & Umur Proyek & 2 & tahun \\
2 & Suku Bunga Bank (Kredit Usaha Rakyat) & 9 & \% efektif \\
3 & Nilai rongsok peralatan & 10 & $\%$ dari harga investasi \\
4 & Biaya perawatan peralatan & 2 & $\%$ dari biaya investasi \\
5 & Pengoperasian mesin produksi & 1 & Jam/hari \\
6 & Biaya sewa tempat usaha & 2.000 .000 & $\mathrm{Rp} / \mathrm{tahun}$ \\
7 & Manajemen usaha & 1.000 .000 & $\mathrm{Rp} / \mathrm{bulan}$ \\
8 & Jam kerja (hari) & 8 & Jam $/ \mathrm{hari}$ \\
9 & Jam kerja (bulan) & 10 & hari/bulan \\
10 & Upah kerja & 50.000 & $\mathrm{Rp} / \mathrm{hari}$ \\
11 & Jumlah tenaga kerja harian & 2 & $\mathrm{orang}$ \\
12 & Harga listrik PLN 900 VA & 1.467 & $\mathrm{Rp} / \mathrm{kwh}$ \\
13 & Daya motor listrik mesin dan peralatan & 0,67 & $\mathrm{HP}$ \\
& & 0,50 & $\mathrm{~kW}$ \\
14 & Biaya Energi listrik + abodemen & $27.294,34$ & $\mathrm{Rp} / \mathrm{bulan}$ \\
15 & Konsumsi Bahan bakar gas & 0,6 & $\mathrm{~kg} / \mathrm{hari}$ \\
16 & Harga gas & 12.500 & $\mathrm{Rp} / \mathrm{kg}$ \\
17 & Biaya bahan bakar gas & 75.000 & $\mathrm{Rp} / \mathrm{bulan}$ \\
18 & Konsumsi air & 0,50 & $\mathrm{kubik} / \mathrm{hari}$ \\
19 & Harga air & 5.000 & $\mathrm{Rp} / \mathrm{kubik}$ \\
20 & Biaya konsumsi air + abodemen & 35.000 & $\mathrm{Rp} / \mathrm{bulan}$ \\
21 & Kapasitas penirisan minyak & 15 & $\mathrm{~kg} / \mathrm{jam}$ \\
22 & Biaya bahan baku pembuatan keripik bayam & 23.685 & $\mathrm{Rp} / \mathrm{Kg}$ \\
23 & Kabel 2) & 150,00 & $\mathrm{Kg} / \mathrm{bulan}$ \\
24 & Harga kemasan (Kapasitas 1 kg) & 850 & $\mathrm{Rp} / \mathrm{kemasan}$ \\
25 & Biaya Kemasan & 127.500 & $\mathrm{Rp} / \mathrm{bulan}$ \\
\hline
\end{tabular}


tempat dan biaya manajemen usaha (karyawan tetap pengelola usaha) (Thoriq dan Sampurno, 2016 ; Thoriq dkk, 2017). Sedangkan biaya penyusutan diperhitungkan menggunakan metode garis lurus (persamaan 3) dan biaya bunga modal dihitung persamaan 4, maka berdasarkan perhitungan dengan menggunakan data pada Tabel 2, besarnya biaya tetap dapat dilihat pada Tabel 6 .

Tabel 6. Biaya tetap usaha keripik bayam

\begin{tabular}{|c|c|c|}
\hline No & Komponen Biaya & $\begin{array}{c}\text { Biaya } \\
\text { (Rp/bulan) }\end{array}$ \\
\hline 1 & $\begin{array}{l}\text { Biaya penyusutan } \\
\text { peralatan }\end{array}$ & 129.938 \\
\hline 2 & $\begin{array}{l}\text { Biaya sewa tempat } \\
\text { usaha }\end{array}$ & 166.667 \\
\hline 3 & $\begin{array}{l}\text { Biaya perawatan } \\
\text { peralatan }\end{array}$ & 5.775 \\
\hline 4 & Manajemen usaha & 1.000 .000 \\
\hline 5 & $\begin{array}{l}\text { Angsuran pinjaman } \\
\text { (pokok + bungga) }\end{array}$ & 343.147 \\
\hline \multicolumn{2}{|r|}{ Total (Rp) } & 1.645 .527 \\
\hline
\end{tabular}

Berdasarkan Tabel 6 terlihat bahwa besarnya biaya tetap usaha produksi keripik bayam adalah Rp. 1.645.527/bulan. Sedangkan biaya variabel dengan waktu kerja 10 hari /bulan terdiri atas biaya bahan baku pembuatan keripik bayam, energi listrik, upah tenaga kerja harian dan biaya air dengan rincian dapat dilihat pada Tabel 7.

Tabel 7. Biaya variabel usaha produksi keripik bayam

\begin{tabular}{clc}
\hline No & \multicolumn{1}{c}{ Komponen Biaya } & $\begin{array}{c}\text { Biaya } \\
\text { (Rp/bulan) }\end{array}$ \\
\hline 1 & $\begin{array}{l}\text { Bahan baku } \\
\text { pembuatan keripik } \\
\text { bayam }\end{array}$ & 3.552 .750 \\
4 & $\begin{array}{l}\text { Upah kerja tenaga } \\
\text { harian }\end{array}$ & 1.000 .000 \\
2 & $\begin{array}{l}\text { Energi listrik + } \\
\text { abodemen }\end{array}$ & 22.934 \\
3 & $\begin{array}{l}\text { Biaya konsumsi air + } \\
\text { abodemen }\end{array}$ & 35.000 \\
5 & $\begin{array}{l}\text { Biaya Bahan bakar gas } \\
6\end{array}$ & 75.000 \\
Biaya Kemasan & 127.500 \\
\hline & Total (Rp) & $\mathbf{4 . 8 1 7 . 5 4 4}$ \\
\hline
\end{tabular}

Berdasarkan Tabel 7, besarnya biaya variabel usaha produksi keripik bayam adalah $\mathrm{Rp}$. 4.817.544/bulan. Sehingga besarnya biaya produksi yang merupakan penjumlahan biaya tetap dan biaya variabel adalah sebesar Rp. 6.463.071/bulan.
Mengacu pada kapasitas mesin spinner sebesar 15 $\mathrm{kg} / \mathrm{jam}$ maka dalam satu bulan kapasitas produksi keripik bayam adalah $150 \mathrm{~kg} /$ bulan. Sehingga besarnya harga pokok produksi (HPP) yang merupakan besarnya biaya produksi dibagi dengan kapasitas produksi adalah sebesar Rp. 43.087 /kg.

\subsection{Net Present Value (NPV) dan Benefit Cost Ratio (BCR)}

Selama periode analisis besarnya pengeluaran berupa investasi peralatan diawal proyek dan biaya produksi yang berasal dari penjumlahan biaya tetap dan biaya variabel. Sedangkan pendapatan usaha berasal dari hasil penjualan keripik bayam dengan harga pasar Rp. 50.000/kg dan nilai rongsok mesin produksi.

Besarnya biaya investasi adalah Rp. 3.465.000, dan biaya produksi adalah sebesar 6.463.071/ bulan, sedangkan pendapatan bulan pertama hingga bulan ketiga usaha produksi keripik bayam yaitu sebesar Rp. 6.000.000 /bulan, pada bulan keempat hingga keenam sebesar Rp. 7.500.000 / bulan dan nilai akhir peralatan yang diasumsikan 10\% dari harga awal yaitu Rp.346.500.

Mengacu pada bunga kredit usaha rakyat (KUR) yaitu sebesar $9 \%$ efektif/tahun didapatkan nilai sekarang pemasukan bersih pada produksi keripik bayam adalah sebesar Rp. 160.024.877/bulan dan besarnya nilai sekarang pengeluaran bersih adalah sebesar Rp.144.936.095/bulan. Dengan menggunakan persamaan (5) didapatkan nilai NPV produksi keripik bayam sebesar Rp. 15.088.782/ bulan sedangkan BCR dihitung menggunakan persamaan (6) yaitu sebesar 1,10.

\subsection{Payback Period (PBP)}

PBP mengindikasikan seberapa cepat modal atau investasi yang telah dikeluarkan dapat segera kembali berdasarkan pemasukan dan pengeluaran dari usaha yang dilakukan. Pendapatan usaha produksi keripik bayam didapat dari hasil penjualan keripik bayam yang diasumsikan pada bulan ke-1 sampai bulan ke-3 hanya $80 \%$ keripik bayam yang terjual dan pada bulan ke-4 sampai bulan ke-24 sebanyak $100 \%$ keripik bayam hasil produksi terjual semua. Rincian pemasukan dan pengeluaran keuangan dapat dilihat pada Tabel 8. 
Tabel 8. Pemasukan dan pengeluaran keuangan produksi keripik bayam

\begin{tabular}{cccc}
\hline Bulan & Pemasukan (Rp/bulan) & Pengeluaran (Rp/bulan) & Saldo (Rp/bulan) \\
\hline 0 & & 3.465 .000 & $(3.465 .000)$ \\
1 & 6.000 .000 & 6.463 .071 & $(3.928 .071)$ \\
2 & 6.000 .000 & 6.463 .071 & $(4.391 .141)$ \\
3 & 6.000 .000 & 6.463 .071 & $(4.854 .212)$ \\
4 & 7.500 .000 & 6.463 .071 & $(3.817 .282)$ \\
5 & 7.500 .000 & 6.463 .071 & $(2.780 .353)$ \\
6 & 7.500 .000 & 6.463 .071 & $(1.743 .423)$ \\
7 & 7.500 .000 & 6.463 .071 & $(706.494)$ \\
8 & 7.500 .000 & 6.463 .071 & 330.436 \\
9 & 7.500 .000 & 6.463 .071 & 1.367 .365 \\
10 & 7.500 .000 & 6.463 .071 & 2.404 .295 \\
11 & 7.500 .000 & 6.463 .071 & 3.441 .224 \\
12 & 7.500 .000 & 6.463 .071 & 4.478 .154 \\
\hline
\end{tabular}

Berdasarkan Tabel 8 terlihat bahwa saldo bernilai positif pada bulan ke-8 pada produksi keripik bayam. Hal ini menunjukkan pada bulan ke-8 usaha produksi mulai mendapatkan keuntungan atau modal investasi telah kembali.

\subsection{Internal Rate of Return (IRR).}

IRR adalah suatu nilai penunjukyang identik dengan seberapa besar suku bunga yang dapat diberikan oleh investasi tersebut dibandingkan dengan suku bunga bankyang berlaku umum (suku bunga pasar atau Minimum Attractive Rate of Return /MARR). Suku bunga MARR yang diacu pada penelitian ini adalah suku bunga deposito PT. Bank Republik Indonesia yaitu sebesar 5,6\% efektif perbulan. Pada suku bunga IRR akan diperoleh NPV $=0$. Perhitungan IRR dilakukan menggunakan persamaan (7) berdasarkan data pada Tabel 5 bulan ke 1 hingga bulan ke 24. Berdasarkan hasil perhitungan besarnya IRR usaha produksi keripik bayam adalah $12 \%$.

\section{KESIMPULAN}

Modifikasi mesin spinner dengan cara menurunkan kecepatan putar dari 532,50 rpm menjadi $258,18 \mathrm{rpm}$ terbukti tetap dapat mengeluarkan kandungan minyak pada keripik bayam dan menghindari terjadinya kerusakan keripik bayam dari 50\% menjadi tidak terdapat keripik bayam yang rusak.
Pada kapasitas produksi keripik bayam $150 \mathrm{~kg} /$ bulan didapatkan biaya produksi sebesar Rp. 6.463.071/bulan dan harga pokok produksi sebesar Rp. 43.087 /kg. Bila keripik bayam dijual dengan harga pasar Rp.50.000/kg dengan asumsi pada bulan ke-1 sampai bulan ke-3 hanya $80 \%$ yang terjual dan pada bulan ke- 4 bulan ke- 24 sebanyak $100 \%$ terjual semua maka didapatkan NPV sebesar Rp. 15.088.782/bulan, BCR sebesar 1,10, IRR sebesar $12 \%$ dan modal akan kembali pada bulan kedelapan.

\section{DAFTAR PUSTAKA}

Amizah S. 2014. Pengaruh mutu, harga dan kemasan terhadap minat beli kripik bayam Elma Di Kecamatan IV Jurai Kabupaten Pesisir Selatan (Skripsi). STKIP PGRI Sumatera Barat.

Hamimi, Tamrin dan Setyani S. 2011. Uji kinerja mesin pengiris minyak goreng pada pengolahan keripik. Jurnal Teknologi dan Industri Hasil Pertanian 16 (1) : 91 - 100

Ilham M. 2017. Pengujian performance mesin peniris minyak goreng pada keripik singkong [tugas akhir]. Politeknik Negeri Padang, Sumatra Barat.

Kastaman R. 2004. Ekonomi Teknik Untuk Pengembangan Kewirausahaan. Bandung (ID) ; Pustaka Giratuna dan ELOC-UNPAD. 
Pertiwi S., dan Purnama D. 2011. Analisis prainvestasi untuk komersialisasi alat pemerah susu sapi semi otomatis tipe engkol di Provinsi Jawa Barat. Jurnal Keteknikan Pertanian 25 (2) : 95-102

Razak A., Apriyanto M. 2014. Formulasi tepung campuran siap pakai berbahan dasar tapioka-mocaf dengan penambahan maltodektrin sebagai tepung pelapis keripik bayam. Jurnal Teknologi Pertanian 3 (1) : 15-27

Sugandi W., Kramadibrata A.M., Fetriyuna, Prabowo Y. 2018. Analisis teknis dan uji kinerja mesin peniris minyak (spinner). Jurnal Ilmiah Rekayasa Pertanian dan Biosistem 6 (1) : 17- 26

Thoriq A., dan Sampurno R.M. 2016. Analisis ekonomi aplikasi mesin pemarut sagu di Kabupaten Teluk Bintuni Papua Barat. Jurnal Teknologi Pertanian 17 (2) : 129138
Jurnal Teknik Pertanian Lampung Vol7, No. 2: 63-71

Thoriq A., Sampurno R.M., dan Nurjanah S. 2017. Evaluasi ekonomi teknik produksi keripik kentang secara manual (studi kasus : Taman Teknologi Pertanian, Cikajang, Kabupaten Garut, Provinsi Jawa Barat). Jurnal Teknotan 11 (2) : 43-54.

Utami GS, Azinar AW. 2017. Iptek bagi masyarakat home industri keripik bayam. JPP Iptek 1(1) : 7-12

Wulandari A, Nunuk SR. 2009. Perbaikan teknik pembuatan keripik menggunakan penirisan minyak di sentra industri makanan ringan Dusun Jiwan, Gondangan, Jogonalan, Klaten. Jurnal Prospect 5(8) : 39-44

Wijayanti R, Budiastra I.B., dan Hasbullah R. 2011. Kajian rekayasa proses penggorengan hampa dan kelayakan usaha produksi keripik pisang. Jurnal Keteknikan Pertanian 25 (2) : 133-140 